\title{
EDITORIAL
}

\section{A AMBIVALÊNCIA DOS DIREITOS FUNDAMENTAIS NO ESTADO DEMOCRÁTICO DE DIREITO}

s direitos fundamentais entendidos, em seu "nascedouro", como
último fundamento de existência, como verdadeiras conquistas em face do Estado, na contemporaneidade, paradoxalmente assumem o papel de último fundamento de existência do Estado. Este, impactado pela globalização e enfrentando crises multifacetadas, conforme visto, já não é mais o centro "absoluto" da organização política. Isso acaba operando uma perda de racionalidade no programa do Direito elaborado pelo próprio Estado.

Uma perspectiva possível, portanto - para se enfocar a importância dos direitos fundamentais, não só para os indivíduos, mas para a manutenção do próprio Estado - está intimamente ligada ao reconhecimento da diferença, ou seja, a partir do sentido ambivalente dos direitos fundamentais o Estado consegue ainda "sobreviver", ligando-se ao futuro. E o futuro, "por ser desconhecido, faz medo. É, pois, uma necessidade imperiosa para qualquer sociedade, pelo menos quando forja alguma ideia do amanhã, dar estatuto e tratamento a esse medo coletivo."1 Por isso,

De todas as instituições jurídicas susceptíveis de obrigar o futuro, a mais importante foi, e ainda é em larga medida, o Estado, mas na condição de pensarmos como poder contínuo, e não apenas como poder soberano. A soberania vê as coisas do lado da vontade e, logo, da capacidade de se impor no instante; a continuidade institucional, pelo contrário, pressupõe a faculdade de durar para lá da mudança de pessoas e através de variações das relações de força. ${ }^{2}$

1 OST, François. 0 tempo do direito. Traduzido por Maria Fernanda Oliveira. Lisboa: Instituto Piaget, 1999, p. 336.

2 Idem, p. 254. 
O sentido que ora se atribui ao termo ambivalência, portanto, é o de uma qualidade que, em tese, possui dois vetores que atuam em sentido contrário, mas que, na prática, paradoxalmente podem se conciliar. Explicando contextualmente esse sentido atribuído ao termo, a função ambivalente e paradoxal dos direitos fundamentais está justamente na perspectiva contemporânea de que eles, ao mesmo tempo em que atuam como "trunfos em face de maiorias eventuais" e, ainda, como freio às eventuais arbitrariedades praticadas pelo próprio Estado, por outro lado esses direitos também reforçam a ideia da necessidade de manutenção desse ente soberano, ou seja, o Estado - ainda que abalado - se mantém fundamentado no discurso de sua importância para a afirmação dos direitos fundamentais.

E para que o Estado se mantenha, convivendo com os riscos contemporâneos, é de suma importância a presença do discurso mediador dos direitos fundamentais. Neste sentido, Claude Lefort parece ter ofertado importantes pistas para uma adequada visão dos direitos fundamentais em tempos de crise do Estado e do direito modernos. Em sua obra na qual intenta dialogar com aqueles que desferiram duras críticas aos direitos humanos - tachando-os de artifícios, que servem como um verdadeiro "véu" utilizado para "mascarar as relações estabelecidas nas sociedades burguesas" -, como foi o caso, em especial, de Karl Marx³, Lefort defende a tese de que "os direitos do homem não são um véu", pois "longe de terem por função mascarar a dissolução dos liames sociais fazendo de cada um, uma mônada -, os direitos do homem atestam e, ao mesmo tempo, suscitam uma nova rede de relações entre os homens." ${ }^{4}$

Nesse sentido, de certa maneira, todos os textos inéditos que vêm ao mundo nesta edição da Revista de Direitos e Garantias Fundamentais, almejam estabelecer novas redes hermenêuticas sobre os direitos humanos (fundamentais).

Assim, o primeiro artigo deste volume da Revista Direitos e Garantias Fundamentais, os autores Leandro Nascimento Rodrigues e Pastora

3 MARX, Karl. A questão judaica. Traduzido por Silvio Donizete Chagas. 4. ed. São Paulo: Centauro, 2002.

4 LEFORT, Claude. Os direitos do homem e o Estado-providência. Traduzido por Eliana M. Souza. In:___. Pensando o político: ensaios sobre democracia, revolução e liberdade. Rio de Janeiro: Paz e Terra, 1991. p. 50. 
do Socorro Teixeira Leal buscam compreender as "correntes" adotadas pelo STF em relação à aplicação dos direitos fundamentais, mais especificamente no âmbito da sua "eficácia horizontal nas relações privadas"

Em seguida, dialogando com o Cinema, mais especificamente com o filme Moonlight, Adilson José Moreira e Humberto Barrionuevo Fabretti abordam a violência sofrida por minorias raciais e sexuais e a sua relação com o chamado "mundo do crime", a partir do conceito específico de "repertório identificatório".

No texto subsequente, na esteira do debate acerca da violência sofrida por minorias no cotidiano, ancorados no pensamento de Michel Foucault, Bárbara Amelize Costa e Adalberto Antonio Batista Arcelo propõem a aplicação de medidas protetivas previstas na Lei Maria da Penha (Lei 11.340/2006) para mulheres transexuais e travestis, rompendo com o senso comum teórico do jurista na construção de sentido da norma jurídica no processo de interpretação/aplicação do direito.

Outro tema importante, também voltado para as minorias que sofrem historicamente com desrespeito constante à sua dignidade, aparece no texto de Luciano Roberto Gulart Cabral Júnior e Francisco Quintanilha Véras Neto, que abordam a questão indígena numa perspectiva "decolonial", tentando superar discursos universalizantes eurocêntricos que se encontram arraigados à cultura ocidental. Temas como o inter e o multiculturalismo vêm à tona neste debate fértil e sempre atual em "terras brasilis".

E por falar em polêmica histórica que envolve um projeto de nação brasileiro, o penúltimo texto desta revista, escrito por Luís Gustavo Gomes Flores e Ivo dos Santos Canabarro, traz uma importante abordagem sobre o período do governo militar à luz da Comissão Nacional da Verdade (CNV), dos Direitos Humanos e do necessário debate acerca da construção de uma memória social no Brasil.

Por fim, Maria Stela Campos da Silva e Bianca Araújo de Oliveira Pereira, tratam de uma questão nevrálgica para o povo brasileiro: a educação. Como relacionar o federalismo da República Velha aos tempos atuais com o atraso provocado por elites conservadoras no desenvolvimento educacional do país? 
Estes são, portanto, os seis artigos científicos que compõem a presente publicação da nossa qualificada revista transdisciplinar, que trabalha os direitos humanos e seus múltiplos significados e aspectos dentro e além do "invólucro" direitos e garantias constitucionais.

Desejamos a todos uma ótima leitura! Desfrutem!

\section{Nelson Camatta Moreira}

Professor do Doutorado, Mestrado e Graduação da FDV. Pós-doutor pela Universidad de Sevilla (bolsa CAPES). Pós-doutor pela Universidade do Vale do Rio dos Sinos (Unisinos). Doutor em Direito pela Unisinos, com estágio anual na Universidade de Coimbra (bolsa CAPES).

Líder do Grupo de Pesquisa CNPq Teoria Crítica do Constitucionalismo, da FDV.

Líder do Grupo de Estudos Direito e Psicanálise (FDV-ES/Escola Lacaniana de Psicanálise de Vitória). 